\title{
Correlation between Motor Ability and Long Jump Skills of Students
}

\author{
Ervan Kastrena*, Adang Suherman, Amung Ma'mun, Eka Nugraha \\ SPs UPI, Program Studi Pendidikan Olahraga, \\ Universitas Pendidikan Indonesia \\ Bandung, Indonesia \\ *ervankastrena@student.upi.edu
}

\begin{abstract}
Objectives: The purpose of this study was to investigate the correlation between motor ability and long jump ability in children adolescent based on public schools. Method: Participants in this study were high school children $(n=60,60$ boys between the ages of eighteen to nineteen years, class $\mathbf{X}$ ). Living in Indonesia the city of Cianjur. Participation selection is based on poor long jump ability. Results and Discussion: Motor ability correlation coefficient with long jump ability r. 0.422 or $p>$ $\alpha 0.05$. This means that the relationship between motor ability and the long jump in the coefficient is quite strong. Conclusion: in doing the optimal long jump, it really requires a high motor ability factor.
\end{abstract}

\section{Keywords-motor ability; long jump; adolescent}

\section{INTRODUCTION}

One of the oldest sports in the world is athletics. In Indonesia Physical Education curriculum, athletics are the compulsory subjects which given since elementary until high school level, according to the Decree of the Minister of Education and Culture no. 0413 / U / 87. One number in athletic sports is the long jump. The long jump is a jumping motion as far as possible consisting of a prefix, repulsion, jumping, drift, and landing in a sandbox [1]. The long jump is a sport that uses all members of the body to jump over horizontal distances using simple movements [2]. In general, the long jump movement was divided into four phases: running, takeoff, flight, and landing [3-5]. In the long jump requires coordination, accuracy, a balance of speed and strength [6], these components are basically inside the student's motor ability and are needed in movements such as running, repulsion, drifting and landing. Some research results show that motor ability factors have a relationship with results in the long jump [7].

The motor ability has been interpreted as an innate ability that is obtained in carrying out motor skills of a general and fundamental nature. Traditionally, it was seen as a combination of fundamental factors for all movements involving physical fitness elements such as strength, speed, agility, flexibility [8,9]. The researchers define motor ability as general physical efficiency, the degree to which a person has developed his innate capacity to learn more skills [8]. Motor ability is a limiting factor for the appearance of one's movements, meaning that the good or bad skills of the long jump are displayed depending on the motor abilities possessed by that person. Significantly, everyone is different in their abilities.

For this reason, motor ability is used as a capacity to show limits that affect the achievement of one's potential in learning a skill. There are two factors that cause differences in motor abilities possessed by each person; the first is genetic factors and the second is non-genetic factors, such as training experience. The results of the research by Jekauc, et al. show that motor ability is a source for building self-concept in physical activity. If the motor ability develops well, it will produce a good performance in exercise and training [10].

Previous research has found that motor skills in boys are superior in coordination, strength, speed, while girls are significantly better at flexibility and balance [11]. Children with poor motor skills are more likely to choose to avoid physical activity because they lack the skills for the activities provided [12]. Henry compared two special motor abilities between reaction time and moving speed and found no correlation between the two 
components [13]. Other studies compare the tasks of balance $[14,15]$ and strength [16] results are correlated low [17].

Based on some of the results of previous studies, to be that the motor ability factor, is still a controversy among researchers, it is because the results obtained are still not consistent. To clarify the motor ability whether it correlates with skill, especially long jump skills, it must be supported by various theoretical perspectives that exist, using adequate statistical methodology and procedures.

Indonesia rarely found literature that discusses the correlation between motor ability and long jump abilities. Therefore, this study aimed to investigate the correlation between motor ability and long jump ability in children aged 18-19 years based on a high school in Indonesia.

\section{MATERIAL AND METHOD}

\section{A. Participant}

Participants in this study were high school children $(n=60,60$ boys between the ages of eighteen to nineteen years, class X). Living in Indonesia the city of Cianjur. Participation selection is based on poor long jump ability.

\section{B. Procedure}

After asking permission from the principal, then two tenth grade physical education teachers were contacted, who agreed to participate in the study, to investigate the correlation between the motor ability and the long jump ability of the students. All tests take place during physical education classes in the morning. Tests and measurements were carried out at 10:00 a.m. The first test is the motor ability, after that the second test is the long jump.

\section{Instrument}

1) Motor ability: To measure the motor level of students' abilities using motor ability test to measure the motor level ability of children aged 4 to 21 years [1820]. This instrument has been successfully used in various studies to determine the motor abilities of children [21-23]. This test shows the validity value $\mathrm{r} 1 / 4$ .80. Retest reliability tests ranged from 0.84 to 0.91 [24] and according to Kambas and Aggeloussis [19], this is a valid test to assess motor skills in children [25]. For more details about the motor skills ability is presented as follows:
TABLE I. MOTOR ABILITY

\begin{tabular}{|c|l|l|}
\hline No. & \multicolumn{1}{|c|}{ Motor Komponen } & \multicolumn{1}{|c|}{ Item Tes } \\
\hline 1. & Explosive Strength. & Long Jump. \\
\hline 2. & Static Strength. & Handgrip \\
\hline 3. & Dynamic Strength. & Back Squat. \\
\hline $\mathbf{4 .}$ & Trunk Strength. & Sorensen Test \\
\hline $\mathbf{5 .}$ & Dynamic Flexibility. & Sit And Reach. \\
\hline $\mathbf{6 .}$ & Balance. & Standing Strok Test. \\
\hline 7. & $\begin{array}{l}\text { The speed of limb } \\
\text { movement. }\end{array}$ & $\begin{array}{l}\text { The Nelson Speed Of } \\
\text { Movement Test. }\end{array}$ \\
\hline $\mathbf{8 .}$ & Bilateral Coordination & Jumping in place. \\
\hline 9. & Stamina. & Blake Test. \\
\hline
\end{tabular}

2) Long jump: The component of squat style long jump technique skills observed consisted of 1) Phase running, 2) Phase take-off, 3) Phase flight, 4) Phase landing. The format of squat style long jump mastery skills was taken from Suherman [26].

\section{Data Analysis}

Data analysis used Statistical Package for the Social Sciences (SPSS) version 22 (IBM, New York, USA). Descriptive statistics are looking for the average value, standard deviation, highest value and lowest value [10, 25] calculated for all variables. Current Pearson product correlation to examine the relationships between variables. Alpha level p 50.05 to find explicit significance $[6,18]$.

\section{RESULTS}

Descriptive statistics related to the results of motor ability tests with long jump are shown in Table 1. Long jump ( $\mathrm{M}=3.47, \mathrm{SD}=1.396)$, Hand grip $(\mathrm{M}=43.97, \mathrm{SD}=$ 2.928), Back squad $(\mathrm{M}=16.28, \mathrm{SD}=.3 .580)$, Sorensen test $(\mathrm{M}=3.38, \mathrm{SD}=1.329)$, Sit and reach $(\mathrm{M}=19.60, \mathrm{SD}=$ 6.090), Standing strock ( $\mathrm{M}=43.97, \mathrm{SD}=2.928)$, The Nelson movement $(\mathrm{M}=49.92, \mathrm{SD}=9.208)$, Jumping in place $(\mathrm{M}=44.12, \mathrm{SD}=.5 .478)$, Balke test $(\mathrm{M}=44.57$, $\mathrm{SD}=4.232)$ and long jump test $(\mathrm{M}=11.83, \mathrm{SD}=2.964)$. For more details, can be seen on Table 3.

TABLE II. DESKRIPTIF STATISTIK MOTOR ABILITY STUDENT IN LONG JUMP

\begin{tabular}{|c|l|l|l|l|}
\hline $\begin{array}{c}\text { Motor } \\
\text { Component }\end{array}$ & Item test & Mean & $\begin{array}{c}\text { Std. } \\
\text { Deviation }\end{array}$ & N \\
\hline $\begin{array}{c}\text { Explosive } \\
\text { Strength }\end{array}$ & Long jump. & 3.47 & 1.396 & 60 \\
\hline Static Strength & Hand grip. & 43.97 & 2.928 & 60 \\
\hline $\begin{array}{c}\text { Dynamic } \\
\text { Strength }\end{array}$ & Back squad. & 16.28 & 3.580 & 60 \\
\hline
\end{tabular}


Table 2. Cont.

\begin{tabular}{|c|c|l|l|l|}
\hline Trunk Strength & $\begin{array}{c}\text { Sorensen } \\
\text { test. }\end{array}$ & 3.38 & 1.329 & 60 \\
\hline $\begin{array}{c}\text { Dynamic } \\
\text { Flexibility }\end{array}$ & $\begin{array}{c}\text { Sit and } \\
\text { reach. }\end{array}$ & 19.60 & 6.090 & 60 \\
\hline Balance & $\begin{array}{c}\text { Standing } \\
\text { strock. }\end{array}$ & 43.97 & 2.928 & 60 \\
\hline $\begin{array}{c}\text { Speed of limb } \\
\text { movement }\end{array}$ & $\begin{array}{c}\text { The nelson } \\
\text { movement. }\end{array}$ & 49.92 & 9.208 & 60 \\
\hline $\begin{array}{c}\text { Bilateral } \\
\text { Coordination }\end{array}$ & $\begin{array}{c}\text { Jumping } \text { in } \\
\text { place. }\end{array}$ & 44.12 & 5.478 & 60 \\
\hline Stamina & $\begin{array}{c}\text { Balke test. } \\
\text { Long jump } \\
\text { test. }\end{array}$ & 44.57 & 4.232 & 60 \\
\hline & & 2.964 & 60 \\
\hline
\end{tabular}

Motor ability correlation coefficients with long jump ability are addressed in Table 4 (r.0. 422> p 0.05). It can be concluded that the relationship between motor ability and long jump in the coefficient category is quite strong.

TABLE III. MOTOR ABILITY CORRELATION COEFFICIENT WITH LONG JUMP

\begin{tabular}{|c|c|c|c|}
\hline Tes & & $\begin{array}{l}\text { Motor } \\
\text { Ability }\end{array}$ & $\begin{array}{c}\text { Long Jump } \\
\text { Test }\end{array}$ \\
\hline \multirow[t]{3}{*}{ Motor Ability } & $\begin{array}{c}\text { Pearson } \\
\text { Correlation }\end{array}$ & 1 & $.422^{* *}$ \\
\hline & Sig. (2-tailed) & & .001 \\
\hline & $N$ & 60 & 60 \\
\hline \multirow[t]{3}{*}{$\begin{array}{l}\text { Long Jump } \\
\text { Test }\end{array}$} & $\begin{array}{c}\text { Pearson } \\
\text { Correlation } \\
\end{array}$ & $.422^{* *}$ & 1 \\
\hline & Sig. (2-tailed) & .001 & \\
\hline & $N$ & 60 & 60 \\
\hline & \multicolumn{3}{|c|}{ **. Correlation is significant at the 0.01 level (2-tailed). } \\
\hline
\end{tabular}

\section{DISCUSSION}

Based on the calculation of Pearson correlation shows that motor ability correlates with long jump ability, this is because in high motor skills there are several components such as speed which is very useful in running the phase, then the power that is useful in the take-off phase, as well as balance that keeps the body balanced when in the flight phase. Maxwell's research results support the results of this study, where motor skills (agility, balance, coordination) tend to contribute significantly to the acquisition of children's movement skills [27]. There are five basic motor skills explosive strength, speed, balance, coordination and flexibility in this study [18]. The explosive strength factor has a very strong correlation with the results of repulsion. The greater the explosive strength possessed by students, the further the results of repulsion are obtained. The speed factor has a very strong correlation with the phase running, because the speed when running the speech gives a correlation with the result of the jump. The balance factor has a correlation with the drift phase which is to maintain the balance of the body to remain stable when floating in the air. Coordination factor has a correlation with the discovery of the body when it will land. And the last factor flexibility has a correlation with the landing phase, the more flexible the body of a student, the better the landing phase is done. Based on these findings, later it will be useful for trainers and physical education teachers in designing and directing training programs for students as an effort to improve motor skills and long jump abilities.

\section{CONCLUSION}

The conclusion in this study, we provide information about the correlation between motor ability and long jump ability. The correlation between motor ability and success in sports has received much attention in recent years. The question of which characteristics determine athletes to achieve peak performance has been proven is motor ability at an early age has an important performance from several basic movement skills [28]. Besides, the importance of motor skills is useful for everyday life [29]. These findings add to the literature which shows that motor skills are an important element of long jump skills.

\section{ACKNOWLEDGMENTS}

This article is part of the assignment for the first author to complete doctoral studies (S3) in the Sports Education program at the Indonesian University of Education. Thank you very much to Prof. Dr. Adang Suherman, M.A., Dr. Amung Ma'mun, M.Pd., Dr. Eka Nugraha, M.Kes. who has contributed to the completion of this article.

\section{REFERENCES}

[1] B. Santoso et al., Pendidikan Jasmani Olahraga dan Kesehatan. Jakarta: Yudhistira, 2007.

[2] B. Zhang, "Takeoff Technical Analysis in Long Jump Based on the Dynamics Statistical Model". Research Journal of Applied Sciences, Engineering, and Technology, vol. 6(24), pp. 45794582, 2013.

[3] H. Zhang, "Pearson correlation study of the long jump athletic injury based on the principal component analysis". Journal of Chemical and Pharmaceutical Research, vol. 5(12), pp. 308-313, 2013. 
[4] M. Coh et al., Kinematic and Biodynamic Model of the Long Jump Technique, 2017.

[5] E. Nugraha, F. Dliss, and M. Asmawi, "Long Jump Training Programs for Indonesian Athletes". IOP Conf. Series: Materials Science and Engineering, vol. 180, pp. 012196, 2017.

[6] M.K. Mishra, and V.S. Rathore, "Speed and agility as predictors of long jump performance of male athletes". Turkish Journal of Sport and Exercise, 2016.

[7] R. Pavlovic, D. Bonacin, and D. Stankovic, "Differences in Kinematic Parameters of the Long Jump between Male and Female Finalists of World Championships - Berlin 2009". International Journal of Science Culture and Sport, 2016.

[8] V. Kumar, "Effect of circuit training program on selected motor abilities among university male". IJPESH, vol. 3(4), pp. 255257,2016

[9] J.S. Sidhu, "Anthropometric parameters and motor abilities among school children's". International Journal of Physiology, Nutrition and Physical Education 2018, vol. 3(1), pp. 366-369, 2018.

[10] D. Jekauc, M.O. Wagner, C. Herrmann, K. Hegazy, and A. Wol, "Does Physical Self-Concept Mediate the Relationship between Motor Abilities and Physical Activity in Adolescents and Young Adults?". PLoS ONE, 2017.

[11] I. Prskalo and M. Hraski, "The relationship between motor abilities, physical activity and gender in preschool children". Merit Research Journal of Education and Review, 2014.

[12] D.S. Nikolic, M.R. Kocic, D.I. Beric, N.T. Cvetkovic, and A.S. Krzalic, "Motor abilities of children in urban and rural areas. Facta Universitatis", Series: Physical Education and Sport, pp. 127-138, 2015.

[13] F.M. Henry, "Reaction time-movement time correlations". Perceptual and Motor Skills, vol. 12(1), pp. 63-66, 1961.

[14] J.C. Bachman, "Motor learning and performance as related to age and sex in two measures of balance coordination. Research Quarterly". American Association for Health, Physical Education and Recreation, vol. 32(2), pp. 123-137, 1961.

[15] J.N. Drowatzky, "Relationship of size constancy to selected measures of motor ability. Research Quarterly". American Association for Health, Physical Education and Recreation, vol. 38(3), pp. 375-379, 1967.

[16] S.M. Berger, Conditioning through vicarious instigation. Psychological review, vol. 69(5), pp. 450, 1962.

[17] B. Hands, F. McIntyre, and H. Parker, The General Motor Ability Hypothesis: An Old Idea Revisited, 2018.

[18] M. Schmidt, F. Egger, V. Benzing, K. Jaeger, A. Conzelmann, C.M. Roebers, and C. Pesce, "Disentangling the relationship between children's motor ability, executive function, and academic achievement”. PLoS ONE, 2017.

[19] C.A. Kambas, and N. Aggeloussis, "Construct validity of the Bruininks-Oseretsky test of motor proficiency-short form for a sample of Greek preschool and primary school children". Perceptual and Motor Skills, vol. 102, pp. 65-75, 2006.

[20] L. Rosenberg, S. Jacobi, and O Bart, "Executive functions and motor ability contribute to children's participation in daily activities". Journal Of Occupational Therapy, Schools, \& Early Intervention.
[21] D.L. Gallahue, and J.C. Ozmun, Understanding motor development. Infants, children, adolescents, adults (6th ed.). NY: McGraw-Hill, 2006.

[22] L. Van Niekerk, "Die effek van 'n intervensieprogram op die motoriese ontwikkeling van straatkinders. Suid-Afrikaanse Tydskrif vir Navorsing" in Sport, Liggaamlike Opvoedkunde en Ontspanning, vol. 29(1), pp. 159e171, 2007.

[23] B.H. Wrotniak, L.H. Epstein, J.M. Dorn, E.J. Katherine, V. Valerie, and A. Kondilis, "The relationship between motor proficiency and physical activity in children". Pediatrics, vol. 118(6), pp. e1758ee1765, 2006

[24] R. Bruininks, and B. Bruininks, The Bruininks-Oseretsky test of motor proficiency. Minneapolis, MN: NCS Pearson, 2005.

[25] L-L. van Niekerk, D. du Toit, and A.E. Pienaar, The correlation between motor proficiency and physical activity in Senior Phase learners in the Potchefstroom area, 2016.

[26] E. Suherman, Common Textbook: Strategi Pembelajaran Matematika Kontemporer. Bandung: JICA UPI Bandung, 2001.

[27] J.P. Maxwell, C.M. Capio, and R.S.W. Masters, "The interaction between motor ability and skill learning in children: Application of implicit and explicit approaches". European Journal of Sports Science, 2016.

[28] T. Ikeda, and O. Aoyagi, "Relationships between gender difference in motor performance and age, movement skills and physical fitness among 3- to 6-year-old Japanise children based on effect size calculated by meta-analysis". School Health, vol. 5, pp. 9-23, 2009.

[29] I. Prskalo, V. Horvat, and M. Hraski, "Play and children's kinesiological activities: a precondition for making daily exercise a habit". Croatian Journal of Education: Hrvatski časopis za odgoj i obrazovanje, vol. 16(Sp. Ed. 1), pp. 57-68, 2014. 